\title{
The Secondary Nature of Gos. Thom. 5:3
}

In chapter 1, I pointed out that when the readings of NHC II and the Oxyrhynchus fragments differ, we do not always have to take the reading preserved by the Oxyrhynchus fragments to be the more original one. In this appendix, I will argue that Gos. Thom. 5 presents us with a case where NHC II has priority over P.Oxy. 4.654. One difference between the two witnesses to the text of saying 5 is quite remarkable: whereas P.Oxy. 4.654 includes Gos. Thom. 5:3, NHC II omits the entire verse. In what follows, I will demonstrate that the Coptic version preserves the original text of the saying and that the extra verse in P.Oxy. 4.654 is a secondary development.

Gos. Thom. 5 (NHC II)

5:1a $\pi € x \in \overline{\mathrm{i}} \mathrm{X} \epsilon$

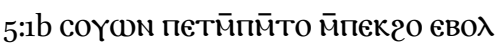

5:1c аүळ пеөнп єрок

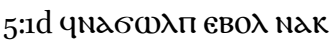

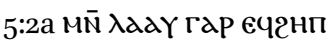

5:2b є4NaOYWN2 $6 B O \lambda$ aN
Gos. Thom. 5 (P.Oxy. 4.654)

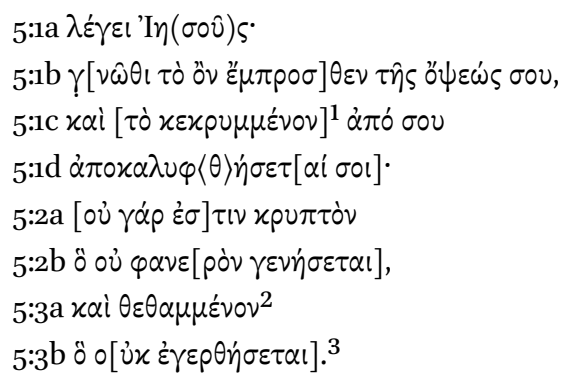

1 This restoration presupposes that 2нп in Gos. Thom. 5:1C and 5:2a corresponds to two cognate words in the Greek text; cf. Johnson 2010, 325-326. The restoration preferred in Attridge

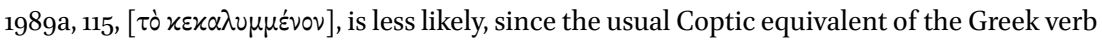
$\varkappa \alpha \lambda \dot{\tau} \pi \tau \omega$ and its cognates is $2 \omega в \bar{c}$; see, e.g., the Sahidic version of Matt 10:26.

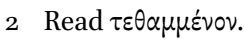

3 This restoration, suggested already in the editio princeps (Grenfell and Hunt 1904, 18) is plausible, though not uncontested (see the apparatus in Attridge 1989a, 115). It is worth noting that the funerary shroud, which contains a parallel to the text of Gos. Thom. 5:3 (published in Puech 1955, 127), appears to be a modern forgery (Alin Suciu, personal communication; cf. the remark by Willy Clarysse and Peter van Minnen that "this is no doubt a falsum" on Leuven Database of Ancient Books, www.trismegistos.org/text/62841). The only image of it is published as the frontispiece of Puech 1978. According to Luijendijk 2011, 39o, the present whereabouts of the shroud are unknown. 
Gos. Thom. 5 (NHC II)

5:1a Jesus said, 5:1b "Recognize what is in your (sg.) sight, 5:1c and that which is hidden from you (sg.) $5: 1 d$ will become plain to you (sg.). $5: 2 a$ For there is nothing hidden 5:2b that will not become manifest."
Gos. Thom. 5 (P.Oxy. 4.654)

5:1a Jesus said, 5:1b "[Recognize what is in] your (sg.) sight, 5:1c and [that which is hidden] from you (sg.) 5:1d will become plain [to you (sg.)]. 5:2a [For there is nothing] hidden $5: 2 \mathrm{~b}$ which [will] not [become] manifest, 5:3a nor buried

$5: 3$ b that [will not be raised]."

A hidden/revealed saying similar to that of Gos. Thom. 5:1c-2b is attested in the Synoptic gospels (Mark 4:22; Matt 10:26; Luke 8:17 and 12:2). Scholars have long realized that Gos. Thom. 5:3a-b, the resurrection strophe, was a secondary expansion of the saying. ${ }^{4}$ It is worth noting, however, that, whereas this strophe is not a part of the original hidden/revealed saying, it may still have been a part of the original the Gospel of Thomas. On this latter issue, scholars have postulated different scenarios. Some have argued that the resurrection strophe was added to saying 5 at some point of the textual transmission of the Gospel of Thomas. ${ }^{5}$ Others have suggested that P.Oxy. 4.654 preserved the original text of the saying. Of this latter camp of scholars, some have thought that the resurrection strophe was deliberately deleted by a later editor. ${ }^{6}$ Others have argued that a copyist could have accidentally omitted it due to a homoeoteleuton ( $\gamma \varepsilon v \dot{\sigma} \sigma \varepsilon \tau \alpha$...

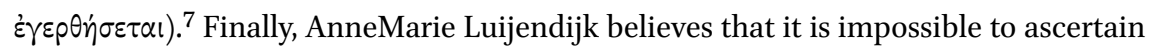
whether the resurrection strophe was omitted from or added to the original text of the Gospel of Thomas. ${ }^{8}$

It is hard to disagree with Luijendijk: caution is always appropriate in matters pertaining to textual criticism. Steven R. Johnson's recent attempt to solve the problem of

4 See, e.g., Jeremias 1958, 16; Bultmann 1972, 91 and 94; Fitzmyer 1974, 383-384.

5 See, e.g., Grobel 1961-1962, 368-369; Marcovich 1988, 67-68; Patterson 1993, 21; Riley 1995, 165167; DeConick 2007, 6o.

6 See, e.g., Mueller 1973, 269; Dunderberg 2006, 62-63.

7 See, e.g., Gärtner 1961, 83-84.

8 Luijendijk 2013, 295: "Whether the longer form of the saying results from an 'orthodox corruption' of the Gospel of Thomas by addition of this phrase to a form of the saying as now preserved in NHC II, or whether the shorter Nag Hammadi reading is an abbreviation by a more spiritually-minded Christian, cannot be determined on the basis of the current evidence." 
Gos. Thom. 5:3a-b is a nice illustration of the fact that you can never be too careful. According to Johnson, it is NHC II that preserves the original Thomasine reading, since the scenario in which the resurrection strophe was added to the original the Gospel of Thomas is much easier to imagine than the alternative. In this case, we simply presume that the Gospel of Thomas originally contained the hidden/revealed saying similar to the one attested by the Synoptics and that, at some point, this Thomasine saying was supplemented by the resurrection strophe. The alternative scenario is much more complicated, since, in this case, "one must postulate two stages of redaction: the insertion of the resurrection strophe at some point of time in the transmission history of the Gospel of Thomas, as reflected in Greek Thomas 5; and its subsequent omission at a later date, as represented by Coptic Thomas $5 . " 9$

While the argument by principle of lex parsimoniae is perfectly acceptableindeed, as Morton Smith put it, history is "the most probable account of what happened"10_it does not seem to apply in this particular situation. Johnson's argument does not seem to work, because both of his proposed scenarios presuppose two redactional stages. Even if Gos. Thom. 5:3a-b were a later expansion of the text, Gos. Thom. 5:1a-b cannot be, since it is present both in N HC II and P.Oxy. 4.654. Because Gos. Thom. 5:1a-b does not have any parallels in the Synoptics, it must belong to the Thomasine redaction. Hence, according to one scenario, the first stage of redaction was the insertion of Gos. Thom. 5:1a-b and the second the insertion of Gos. Thom. 5:3a-b; according to another scenario, the first stage of redaction was the insertion of Gos. Thom. 5:1a-b and $5: 3 \mathrm{a}-\mathrm{b}$ and the second the omission of Gos. Thom. 5:3a-b.

\section{Pre-Thomasine saying First redaction (origi- Second redaction nal Gospel of Thomas)}

$\begin{array}{llll}\text { Scenario \#1 } & \text { Gos. Thom. 5:1c-2b } & + \text { Gos. Thom. 5:1a-b } & + \text { Gos. Thom. 5:3a-b } \\ \text { Scenario \#2 } & \text { Gos. Thom. 5:1c-2b } & + \text { Gos. Thom. 5:1a-b } & \text { - Gos. Thom. 5:3a-b } \\ & & + \text { Gos. Thom. 5:3a-b } & \end{array}$

Thus, what is left of Johnson's argument is an appeal to common sense: Scenario \#2 appears to be a little suspicious, since it presupposes that the same strophe was first inserted and then omitted. Yet this hypothetical course of events is imaginable and cannot be dismissed without further argumentation to the contrary.

\footnotetext{
9 Johnson 2002, 178-179.

10 Smith 1996, 1:4.
} 
Nevertheless, I do not think that the situation is hopeless. I suggest that Scenario \#1 is more likely and that the formal structure of saying 5 indicates that Gos. Thom. 5:3ab was a secondary expansion. First, there can be little doubt that the Synoptic/preThomasine version of the hidden/revealed saying has a parallel structure: hiddenmanifest / hidden-manifest $(\mathrm{A}-\mathrm{B} / \mathrm{A}-\mathrm{B})$. The following synoptic table illustrates the structure of the saying according to Gos. Thom. 5:1c-2b and Matt 10:26:

Gos. Thom. 5:1c-2b

\begin{tabular}{|c|c|c|c|c|}
\hline A & $5: 1 c$ & 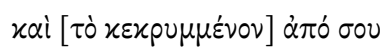 & A & 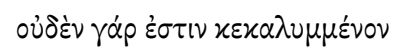 \\
\hline B & $5: 1 \mathrm{~d}$ & $\dot{\alpha} \pi 0 x \alpha \lambda \nu \varphi\langle\theta\rangle \dot{n} \sigma \varepsilon \tau\left[\alpha i{ }^{\prime} \sigma \circ l\right] \cdot$ & B & ö ởx $\alpha \dot{\pi} 0 x \alpha \lambda \nu \varphi \theta \dot{\eta} \sigma \varepsilon \tau \alpha \mathrm{l}$ \\
\hline A & $5: 2 a$ & 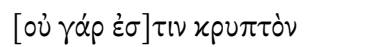 & A & 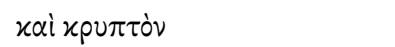 \\
\hline в & $5: 2 b$ & ö ov $\varphi \alpha \nu \varepsilon[\rho \dot{\nu} \nu \gamma \varepsilon \nu \eta ́ \sigma \varepsilon \tau \alpha l]$. & в & ö ov่ $\gamma \nu \omega \sigma \theta \dot{\eta} \sigma \varepsilon \tau \alpha l$. \\
\hline
\end{tabular}

Once the hidden/revealed saying became a part of the Gospel of Thomas and was expanded by Gos. Thom. 5:1b, it could no longer retain the formal structure it had before. The redactor, however, did not destroy or disregard the parallelism of the saying; rather, he transformed it. Whereas in the pre-Thomasine version of the saying, Gos. Thom. 5:1c and 5:1d functioned as two opposing units, in the Gospel of Thomas they form a single unit: Gos. Thom. 5:1c-d. In this new parallel structure, Gos. Thom. 5:1cd stands opposite to Gos. Thom. 5:1b, just as Gos. Thom. 5:2b stands opposite to Gos. Thom. 5:2a. As a result, the redactor came up with a chiastic saying: come to know that which is manifest and you will know that which is hidden, for there is nothing hidden which will not become manifest $(\mathrm{B}-\mathrm{A} / \mathrm{A}-\mathrm{B}) .{ }^{11}$ The following table illustrates the new parallel structure of the saying:

\begin{tabular}{|c|c|c|}
\hline B & $5: 1 b$ & 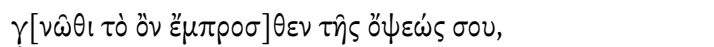 \\
\hline A & $5: 1 \mathrm{c}-\mathrm{d}$ & 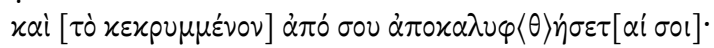 \\
\hline A & $5: 2 \mathrm{a}$ & 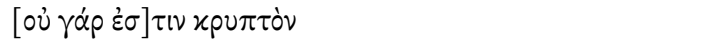 \\
\hline B & $5: 2 b$ & 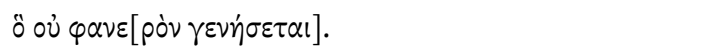 \\
\hline
\end{tabular}

The fact that Gos. Thom. $5: 1 b-2 b$ is a chiasm is crucial for the textual criticism of the saying. After the insertion of Gos. Thom. 5:1b, the saying acquired its chiastic structure. Gos. Thom. 5:3a-b, the resurrection strophe, disturbs this chiastic structure; hence, it

11 Chiasm appears to be one of the more frequently-used structural devices in the Gospel of Thomas. See the discussion in chapter 8 (pp. 223-225). 
seems reasonable to give preference to Scenario \#1, which presupposes the insertion of Gos. Thom. 5:1a-b and 5:3a-b at two different redactional stages. Thus, Gos. Thom. 5:3a-b must be a later addition.

Moreover, it seems that the person who added the resurrection strophe to the saying did not recognize that it was a chiasm. Having ignored Gos. Thom. 5:1b, he disregarded the structural difference between the Thomasine and Synoptic versions of the hidden/revealed saying. Treating the Thomasine version of the saying as if it were formally identical with the Synoptic one $(\mathrm{A}-\mathrm{B} / \mathrm{A}-\mathrm{B})$, he inserted Gos. Thom. 5:3a-b as a third parallel unit, where being buried and being raised correspond to the being hidden and being manifest of the first two parallel members. As a result, he came up with the parallel structure $(\mathrm{A}-\mathrm{B} / \mathrm{A}-\mathrm{B} / \mathrm{A}-\mathrm{B})$ that follows Gos. Thom. 5:1a-b:

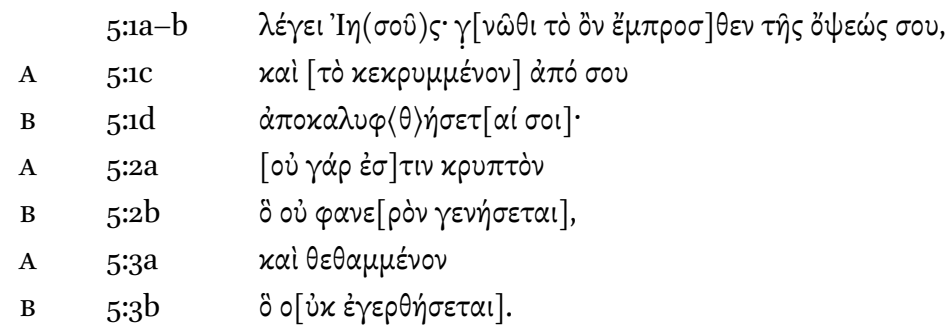

In sum, there were three stages in the development of the hidden/revealed saying: (1) the pre-Thomasine version, attested by the Synoptics; (2) the original Thomasine version, attested by NHC II; (3) the secondary expansion of the Thomasine text, attested by P.Oxy. 4.654. As this survey has demonstrated, saying 5 provides us with an example of the priority of the Coptic text over the Greek fragments of the Gospel of Thomas. 